\title{
Age matters
}

\section{Impact of data-driven CSF protein upper reference limits in Guillain-Barré}

\section{syndrome}

Pierre R. Bourque, FRCP(C), John Brooks, $\operatorname{FRCP}(C)$, Christopher R. McCudden, $\operatorname{FRCP}(C)$, Jodi Warman-Chardon, $\operatorname{FRCP}(C)$, and Ari Breiner, $\operatorname{FRCP}(C)$

Neurol Neuroimmunol Neuroinflamm 2019;6:e576. doi:10.1212/NXI.0000000000000576

\section{Abstract}

\section{Objective}

We conducted a retrospective review of patients with a diagnosis of Guillain-Barré syndrome (GBS) to assess the diagnostic impact of applying age-adjusted upper limits for CSF total protein (CSF-TP) supported by a systematic literature review.

\section{Methods}

Cases coded as GBS or inflammatory neuropathy for the period 2001-2016 at The Ottawa Hospital were reviewed. Cases were included if they met the Brighton criteria for GBS with a diagnostic certainty level 1 or 2 and had contemporaneous CSF-TP data. We excluded cases with CSF pleocytosis >50 and cases with Miller-Fisher syndrome. Age-adjusted reference limits were compared with conventional 0.45 and $0.6 \mathrm{~g} / \mathrm{L}$ upper limits.

\section{Results}

One hundred thirty-eight cases met the study criteria, with a mean age of 47 years. The mean interval from symptom onset to lumbar puncture was 7.9 days, and mean CSF-TP was $1.23 \mathrm{~g} / \mathrm{L}$. There was a strong correlation between rising CSF-TP and time to lumbar puncture. Ageadjusted CSF-TP had a significantly lower sensitivity of only $45 \%$ in the first week (32\% in the first 3 days) compared with $70 \%$ in the first week for the $0.45 \mathrm{~g} / \mathrm{L}$ limit. All upper limits gained high sensitivity after the first week.

\section{Conclusions}

The low sensitivity of CSF-TP for the diagnosis of GBS is exacerbated by age-adjusted upper limits. The main role of lumbar puncture in GBS in the first week may be to help exclude other inflammatory or neoplastic etiologies of acute neuropathy. After the first week, the magnitude of the CSF-TP rise reduces the effect of different upper reference limits.

\author{
Correspondence \\ Dr. Bourque \\ pbourque@toh.ca
}

From The Ottawa Hospital (P.R.B., J.B., J.W.-C., A.B.), University of Ottawa; The Ottawa Hospital Research Institute (P.R.B., C.R.M., J.W.-C., A.B.); and Department of Pathology and Laboratory Medicine (C.R.M.), The Ottawa Hospital, Ottawa, Canada. 


\section{Glossary}

CSF-TP = CSF total protein; GBS = Guillain-Barré syndrome; Ig = immunoglobulin; URL $=$ upper reference limit.

The presence of albuminocytologic dissociation is a wellvalidated diagnostic criterion for Guillain-Barré syndrome (GBS). ${ }^{1}$ Its severity is correlated with the timing of lumbar puncture. CSF total protein (CSF-TP) may only be a crude surrogate measure of disrupted blood-nerve barrier permeability and intrathecal antibody synthesis compared with serum/CSF ratios of albumin and immunoglobulin (Ig) G. ${ }^{2}$ Nonetheless, CSF-TP remains the most frequently performed CSF diagnostic test worldwide in the assessment of suspected polyradiculoneuropathy of acute onset, and it may significantly influence the decision to initiate treatment with IVIg or plasmapheresis. Electrodiagnostic studies also offer critical clues to detect and characterize peripheral nerve demyelination and axonopathy but are less routinely available worldwide and are normal in up to $20 \%$ of patients in the first week. ${ }^{3}$

Recent rigorous laboratory studies and a systematic review of the literature have validated significantly higher upper reference limits (URLs) than the $0.45 \mathrm{~g} / \mathrm{L}(45 \mathrm{mg} \%)$ limit commonly used by hospital laboratories worldwide and commonly referenced in the literature. ${ }^{4}$ This study explores the impact of newer data-driven age-adjusted upper reference values for CSF-TP for the diagnosis of GBS.

\section{Methods}

All cases coded at the time of hospital discharge as either "Guillain-Barré syndrome" or "Inflammatory Neuropathy" for the years 2001-2016 were reviewed by a neuromuscular specialist (P.R.B). Cases were included in the analysis if they met the Brighton criteria ${ }^{5}$ for GBS with a diagnostic certainty level 1 or 2 and had contemporaneous CSF-TP data. All patients had to present a mostly symmetric progressive pattern of limb and/or cranial nerve weakness with a monophasic course peaking within 28 days. Cases with a CSF white blood cell count greater than 50 were excluded. Cases with MillerFisher syndrome, acute motor axonal neuropathy, and acute motor and sensory axonal neuropathy were excluded, but focal variants with bifacial or pharyngo-brachial onset were included. Clinical onset of GBS was defined as the earliest documentation of sustained new paresthesia or sustained symmetrical muscular paresis.

For the correlation between CSF-TP and days-to-lumbar puncture, an F-statistic test was performed, and a $R^{2}$ coefficient calculated. Days-to-lumbar puncture times were grouped by weekly intervals. The diagnostic sensitivity of CSF-TP was calculated as abnormal results/all cases of GBS. This was first calculated using our published institutional upper reference values. ${ }^{6}$ This data set, based on 6,068 samples, establishes URLs that are age adjusted, with representative values of $0.54 \mathrm{~g} / \mathrm{L}$ at age 30 years, $0.57 \mathrm{~g} / \mathrm{L}$ at age 40 years, $0.60 \mathrm{~g} / \mathrm{L}$ at age 50 years, $0.63 \mathrm{~g} / \mathrm{L}$ at age 60 years, and $0.67 \mathrm{~g} / \mathrm{L}$ at age 70 years. Diagnostic sensitivity was also calculated for the widely used fixed $0.45 \mathrm{~g} / \mathrm{L}$ upper conventional limit and with a fixed $0.6 \mathrm{~g} / \mathrm{L}$ upper limit. These 2 ageindependent limits were compared with the age-adjusted norms using the McNemar test.

\section{Standard protocol approvals, registrations, and patient consents}

The study was approved by the Ottawa Hospital Research Institute Ethics Board (protocol 20160863).

\section{Data availability}

Anonymized data will be shared by request from any qualified investigator.

\section{Results}

Of 392 cases coded as GBS in the database, 152 were excluded based on inconclusive documentation, coding error, or a more likely non-GBS diagnosis. Forty-eight GBS cases were excluded for lack of contemporaneous CSF-TP results, and 19 cases were excluded because their subsequent clinical course was diagnostic of chronic inflammatory demyelinating polyneuropathy. Fifteen of these patients presented as acute-onset chronic inflammatory demyelinating polyneuropathy, initially mimicking acute inflammatory demyelinating polyneuropathy, with a mean CSF-TP of $1.18 \mathrm{~g} / \mathrm{L}$ for the 13 cases subjected to lumbar puncture. Eighteen cases were excluded because they fulfilled the criteria for Miller Fisher syndrome. One hundred thirty-eight cases met all criteria (mean age 47 years, $56 \%$ males). Electrodiagnostic studies were available for review in all but 6 patients.

The mean number of days between clinical onset and lumbar puncture was 7.9 days (range, 1-25 days). The mean CSF white blood cell count was 3.0/ $\mu \mathrm{L}$. The mean CSF-TP for all GBS cases was $1.23 \mathrm{~g} / \mathrm{L}$ (range, 0.28-8.62 g/L). There was a correlation of rising CSF-TP with increasing number of days between clinical onset and the number of days to lumbar puncture $(p=0.00048$, figure). During the first week after onset, applying data-driven reference intervals resulted in a sensitivity of only $45 \%$ compared with a sensitivity of $70 \%$ with the conventional fixed $0.45 \mathrm{~g} / \mathrm{L}$ upper limit (table). The age-adjusted URL had even lower sensitivity (32\%) in the $0-3$ day interval. The age-adjusted upper limits did not perform significantly differently compared with the fixed $0.6 \mathrm{~g} / \mathrm{L}$ upper limit. All 3 upper limits had statistically similar high sensitivities in the range of $74 \%-87 \%$ in the second week and $92 \%-100 \%$ subsequently. 
Table Diagnostic sensitivity at different time intervals and CSF-TP reference limits

\begin{tabular}{llll}
\hline & $\mathbf{0 - 6}$ days & $\mathbf{7 - 1 3}$ days & >13 days \\
\hline Age-adjusted reference data & $0.45(30 / 66)$ & $0.74(34 / 46)$ & $0.92(24 / 26)$ \\
\hline $\mathbf{0 . 6} \mathbf{g} / \mathbf{L}$ & $0.47(31 / 66) p=1$ & $0.76(35 / 46) p=1$ & $0.96(25 / 26) p=1$ \\
\hline $\mathbf{0 . 4 5} \mathbf{~ g / L}$ & $0.7(46 / 66) p<0.001^{\text {a }}$ & $0.87(40 / 46) p=0.041$ & $1(26 / 26) p=0.480$
\end{tabular}

Abbreviations: GBS = Guillain-Barré syndrome; CSF-TP = CSF total protein.

Sensitivity is calculated as GBS cases with elevated protein/all GBS cases (numbers in brackets). It is expressed as a function of the time interval (clinical onset to lumbar puncture) and 3 different upper limits: age adjusted (institutional reference study), 0.60 , and $0.45 \mathrm{~g} / \mathrm{L}$. The $p$ values are computed using the McNemar test, comparing 0.6 and $0.45 \mathrm{~g} / \mathrm{L}$ to the age-adjusted reference data. The threshold for significance using the Bonferroni correction is 0.008 .

a There is a significant difference for the $0.45 \mathrm{~g} / \mathrm{L}$ limit at the $0-6$ day interval only.

\section{Discussion}

Consensus guidelines for the diagnosis of GBS allow the institution where testing is performed to define their CSF-TP URL. ${ }^{5}$ A laboratory practice survey revealed that over $85 \%$ of clinical centers worldwide presently use an antiquated arbitrary age-independent upper limit of $0.45 \mathrm{~g} / \mathrm{L}$, dating back to the seminal 1938 monograph of Houston Merritt. ${ }^{7}$ A recent systematic review supports significantly higher URL that should be stratified by age, as was used in the present study. ${ }^{4}$

Our study reaffirms the finding of time-dependent CSF-TP elevation in patients with GBS, as described in series pooling data from observational and therapeutic studies ${ }^{8}$ or from several Asian countries. ${ }^{9}$ Our study shows that within the first week, the sensitivity of CSF studies is quite low, in the order of $45 \%$. Using an age-independent CSF-TP URL of $0.45 \mathrm{~g} / \mathrm{L}$ might artificially boost sensitivity to $70 \%$ within the first week of GBS onset, but risks lowering specificity early in the disease course, when costly treatment decisions are made, and accurate diagnosis is paramount.

The other commonly used value of $0.60 \mathrm{~g} / \mathrm{L}$, quoted in some recent laboratory reference texts, more closely matched the validated age-dependent reference values. It may constitute a reasonable better simple approximation for clinical practice. All URLs tested had similar high sensitivities for lumbar punctures performed more than 1 week after symptom onset, likely because of the large magnitude of the CSF-TP elevation that eventually occurs in GBS, with a mean value of $1.23 \mathrm{~g} / \mathrm{L}$ in our data set. The diagnostic yield of CSF-TP in the first week may also be influenced by the criterion used to define the GBS time of onset. We judged that prominent sustained new paresthesia or cranial neuropathy would be considered by most clinicians to be a reliable first index manifestations of GBS. In the study of Fokke et al, ${ }^{8}$ onset of weakness was the sole criterion, which would lead to lower values for the time to lumbar puncture.

The main potential benefit of raising CSF-TP URL, using data-driven age-adjusted values supported by the recent literature, is a predictable gain in specificity. A limitation of our analysis, similar to other series, is the lack of data necessary to accurately measure specificity. This would require a systematic hospital chart review to also capture all cases in which GBS was a suspected diagnosis at the time of lumbar puncture and GBS was excluded as a final diagnosis. Nonetheless, this study highlights that CSF-TP has low sensitivity in the first

Figure Relation of CSF-TP value and time between clinical onset and lumbar puncture

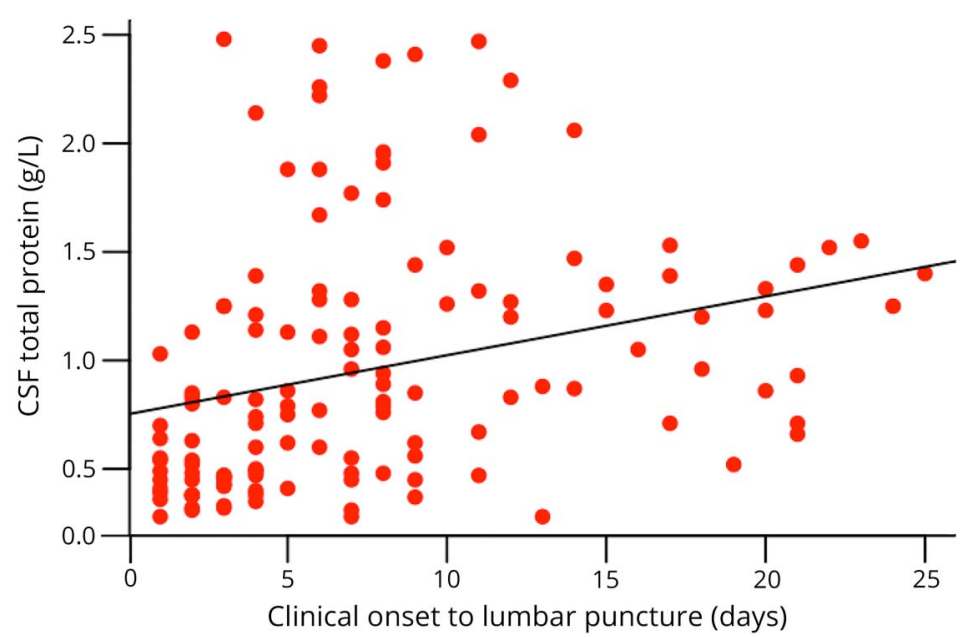

The Tukey method was used to remove outliers from the data set before computing the trend line. Although the F-statistic shows a positive correlation in the relationship between CSF-TP and time to lumbar puncture $(p=0.00048)$, a large degree of variability in CSF-TP values remains unaccounted for $\left(R^{2}=0.071\right)$. CSF-TP $=$ CSF total protein. 
week (when lumbar puncture mostly helps to rule out infectious or neoplastic disease) and only acquires a true high sensitivity for GBS by the second week.

\section{Study funding}

No targeted funding reported.

\section{Disclosure}

The authors report no disclosures. Go to Neurology.org/NN for full disclosures.

\section{Publication history}

Received by Neurology: Neuroimmunology \& Neuroinflammation March 7, 2019. Accepted in final form March 28, 2019.

\section{Appendix Authors}

\begin{tabular}{llll}
\hline Author & Location & Role & Contributions \\
\hline $\begin{array}{l}\text { Pierre R. } \\
\text { Bourque, } \\
\text { FRCP(C) }\end{array}$ & $\begin{array}{l}\text { Ottawa, } \\
\text { Canada }\end{array}$ & $\begin{array}{l}\text { First and } \\
\text { corresponding } \\
\text { author }\end{array}$ & $\begin{array}{l}\text { Study concept and } \\
\text { design, acquisition of } \\
\text { data, interpretation and } \\
\text { analysis of data, and } \\
\text { study supervision }\end{array}$ \\
\hline $\begin{array}{l}\text { John Brooks, } \\
\text { FRCP(C) }\end{array}$ & $\begin{array}{l}\text { Ottawa, } \\
\text { Canada }\end{array}$ & Author & $\begin{array}{l}\text { Statistical analysis of } \\
\text { data, interpretation and } \\
\text { analysis, and critical } \\
\text { revision of the } \\
\text { manuscript }\end{array}$ \\
\hline $\begin{array}{l}\text { Christopher R. } \\
\text { McCudden, }\end{array}$ & $\begin{array}{l}\text { Ottawa, } \\
\text { FRCP(C) }\end{array}$ & Authadar & $\begin{array}{l}\text { Interpretation and } \\
\text { analysis of data and } \\
\text { critical revision of the } \\
\text { manuscript for } \\
\text { important intellectual } \\
\text { content }\end{array}$ \\
\hline & & & \\
\hline
\end{tabular}

Appendix (continued)

\begin{tabular}{llll}
\hline Author & Location & Role & Contributions \\
\hline $\begin{array}{l}\text { Jodi Warman- } \\
\text { Chardon, } \\
\text { FRCP(C) }\end{array}$ & $\begin{array}{l}\text { Ottawa, } \\
\text { Canada }\end{array}$ & Author & $\begin{array}{l}\text { Critical revision of the } \\
\text { manuscript for } \\
\text { important intellectual } \\
\text { content }\end{array}$ \\
\hline $\begin{array}{l}\text { Ari Breiner, } \\
\text { FRCP(C) }\end{array}$ & Ottawa, Author & $\begin{array}{l}\text { Interpretation and } \\
\text { analysis of data and } \\
\text { Critical revision of } \\
\text { the manuscript for } \\
\text { important intellectual } \\
\text { content }\end{array}$ \\
& & Andal
\end{tabular}

\section{References}

1. Asbury AK, Cornblath DR. Assessment of current diagnostic criteria for GuillainBarre syndrome. Ann Neurol 1990;27(suppl):S21-S24.

2. Deisenhammer F, Bartos A, Egg R, et al. Guidelines on routine cerebrospinal fluid analysis: report from an EFNS task force. Eur J Neurol 2006;13:913-922.

3. Uncini A, Kuwabara S. Electrodiagnostic criteria for Guillain-Barre syndrome: a critical revision and the need for an update. Clin Neurophysiol 2012;123: $1487-1495$.

4. Breiner A, Moher D, Brooks J, et al. Adult CSF total protein upper reference limits should be age-partitioned and significantly higher than $0.45 \mathrm{~g} / \mathrm{L}$ : a systematic review. J Neurol 2019;266:616-624.

5. Sejvar JJ, Kohl KS, Gidudu J, et al. Guillain-Barré syndrome and Fisher syndrome: case definitions and guidelines for collection, analysis, and presentation of immunization safety data. Vaccine 2011;29:599-612.

6. McCudden CR, Brooks J, Figurado P, Bourque PR. Cerebrospinal fluid total protein reference intervals derived from 20 years of patient data. Clin Chem 2017;63: 1856-1865.

7. Bourque PR, Breiner A, Moher D, et al. Adult CSF total protein: higher upper reference limits should be considered worldwide: a web-based survey. J Neurol Sci 2019;396:48-51.

8. Fokke C, van den Berg B, Drenthen J, Walgaard C, van Doorn PA, Jacobs BC Diagnosis of Guillain-Barré syndrome and validation of Brighton criteria. Brain 2014; 137:33-43.

9. Wong AH, Umapathi T, Nishimoto Y, Wang YZ, Chan YC, Yuki N. Cytoalbuminologic dissociation in Asian patients with Guillain-Barre and Miller Fisher syndromes. J Peripher Nerv Syst 2015;20:47-51. 


\section{Neurology \\ Neuroimmunology \& Neuroinflammation}

\section{Age matters: Impact of data-driven CSF protein upper reference limits in Guillain-Barré syndrome}

Pierre R. Bourque, John Brooks, Christopher R. McCudden, et al.

Neurol Neuroimmunol Neuroinflamm 2019;6;

DOI 10.1212/NXI.0000000000000576

This information is current as of May 21, 2019

\section{Updated Information \& Services}

References

Subspecialty Collections

Permissions \& Licensing

Reprints including high resolution figures, can be found at:

http://nn.neurology.org/content/6/4/e576.full.html

This article cites 9 articles, 1 of which you can access for free at: http://nn.neurology.org/content/6/4/e576.full.html\#\#ref-list-1

This article, along with others on similar topics, appears in the following collection(s):

All Clinical Neurology

http://nn.neurology.org//cgi/collection/all_clinical_neurology

Cerebrospinal Fluid

http://nn.neurology.org//cgi/collection/cerebrospinal_fluid

Guillain-Barre syndrome

http://nn.neurology.org//cgi/collection/guillainbarre_syndrome

Peripheral neuropathy

http://nn.neurology.org//cgi/collection/peripheral_neuropathy

Information about reproducing this article in parts (figures,tables) or in its entirety can be found online at:

http://nn.neurology.org/misc/about.xhtml\#permissions

Information about ordering reprints can be found online:

http://nn.neurology.org/misc/addir.xhtml\#reprintsus

Neurol Neuroimmunol Neuroinflamm is an official journal of the American Academy of Neurology.

Published since April 2014, it is an open-access, online-only, continuous publication journal. Copyright

Copyright () 2019 The Author(s). Published by Wolters Kluwer Health, Inc. on behalf of the American

Academy of Neurology.. All rights reserved. Online ISSN: 2332-7812.

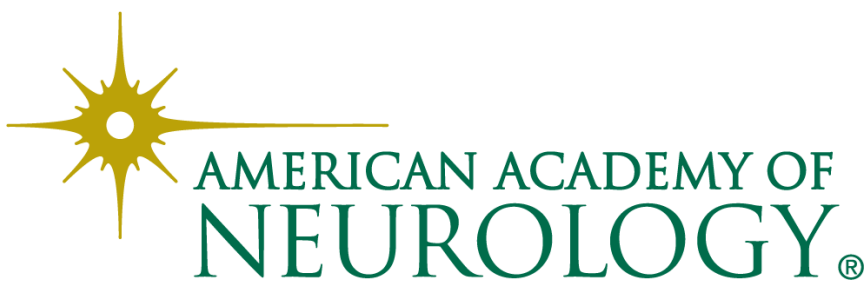

